\title{
Mendeleyev revisited
}

\author{
E. G. Marks ${ }^{1}$. J. A. Marks ${ }^{2}$ (D)
}

Accepted: 23 March 2021 / Published online: 10 April 2021

(C) The Author(s) 2021

\begin{abstract}
Despite the periodic table having been discovered by chemists half a century before the discovery of electronic structure, modern designs are invariably based on physicists' definition of periods. This table is a chemists' table, reverting to the phenomenal periods that led to the table's discovery. In doing so, the position of hydrogen is clarified.
\end{abstract}

Keywords Definition of period $\cdot$ Chemists' periodic table $\cdot$ Mendeleyev $\cdot$ Sommerfeld

This paper is an improvement upon the authors' "Newlands Revisited" (hereinafter abbreviated NR) (Marks and Marks 2010) and many of its references as well as the paper itself are relevant here. The Periodic Table is the foundation of chemistry so any improvement in its design warrants publication in Foundations of Chemistry. From Boyle's 1661 definition (Boyle 2003) of an element and Lavoisier's 1789 practical application (Lavoisier 1789) of it, chemistry launched into a swift development expedited by Avogadro's hypothesis of 1811 (Avogadro 1811) and Faraday's electrochemistry of 1833 (Faraday 1834). In the wake of the 1860 Karlsruhe Congress where these ideas were brought together, the periodic table rapidly developed, culminating in Mendeleyev's table of 1869 (Mendeleyev 1869). This was the fruit of an encyclopædic knowledge of the chemical elements half a century before the discovery of electronic structure by Bohr and Sommerfeld (Bohr 1913; Sommerfeld 1916). On electronic structure, Greenwood and Earnshaw write: "It should always be remembered that it is incorrect to 'deduce' known chemical phenomena from theoretical models; the proper relationship is that the currently accepted theoretical models interpret the facts and suggest new experiments..." (Greenwood and Earnshaw 1993). John Christie of Melbourne expressed it more pithily: "It is chemical properties and behaviour that determine the shape of the periodic table, and electronic structure that explains and rationalizes it, not the other way around." (Christie 2001). This is dramatically illustrated

We express our appreciation for stimulating correspondence on the periodic table and for his book "The Periodic Table: Past, Present and Future" to Professor Geof Rayner-Canham of Newfoundland.

Erstwhile Clinical Director Psychiatry, Gisborne, Newzealand; now Vienna, Austria

J. A. Marks

johnmarks9@hotmail.com

1 Harrogate Lunar Society, Yorkshire, England

2 Vienna, Austria 
by Be not being an inert gas, with physicists offering post hoc explanations, such as $s p^{3}$ hybridization, as to why this should be so.

Most chemists agree that one of the most salient markers of the periodic table is the group of inert gases. Indeed, they are currently used to define the periods and are corroborated by Bohr's radial quantum number. Between the first and second marker, Ne, are what Mendeleyev called his main groups (Russian: 'Основные Группы', German: 'Hauptgruppen'). It is of note that hydrogen falls just before the first inert gas helium and, consequently, one should expect an analogue (fluorine) to fall just before neon and, in this rearrangement of Mendeleyev, under hydrogen (Fig. 1).

Instead of the second period being completed at $\mathrm{Be}$, a further eight elements are added to He to land on the next inert gas. The extra elements created by the Sommerfeld 'splitting' ("Sommerfeldsche aufspaltung") follow after the inert gases. Hence the gap, when Sommerfeld's subgroups ("Nebengruppen") are added, occurs between He and Li. A further ten are added with the $d$-elements (Nebengruppen A) and a further fourteen with the $f$-elements (Nebengruppen $B$ ). These clearly cannot be easily accommodated within Mendeleyev's original eight main groups. Running them sequentially under the main groups, these subgroups fall felicitously to reflect persisting echoes of the main groups, so that $\mathrm{Mn}$ falls under $\mathrm{Cl}$, reflecting $\mathrm{MnO}^{-4}, \mathrm{Mn}_{2} \mathrm{O}_{7}$ and $\mathrm{ClO}^{-4}, \mathrm{Cl}_{2} \mathrm{O}_{7}$; Fe falls in Group VIII with $\mathrm{RuO}_{4}$ and $\mathrm{OsO}_{4}$ reflecting $\mathrm{XeO}_{4} . \mathrm{PuO}_{4}$, although unstable, is an example of the 'main group echo' extending throughout the periodic table. With the exception of monovalent Tm, Group I is well established and Group II is completely established with stable $\mathrm{Yb}^{+2}$. Groups III, IV, V and VI are similarly complete with the

\section{Mendeleyev Revisited}

\begin{tabular}{|c|c|c|c|c|c|c|c|c|c|c|c|c|c|c|}
\hline Group & $-1 / \mathrm{VII}$ & $0 / \mathrm{VIII}$ & & & & & & & I & II & III & IV & $\mathrm{V}$ & $\mathrm{VI}$ \\
\hline riods: $1 s t$ & $\mathrm{H}$ & $\mathrm{He}$ & & & & & & & $\mathrm{Li}$ & $\mathrm{Be}$ & B & $\mathrm{C}$ & $\mathrm{N}$ & $\mathrm{O}$ \\
\hline 2nd & $\mathrm{F}$ & $\mathrm{Ne}$ & & & & & & & $\mathrm{Na}$ & $\mathrm{Mg}$ & Al & $\mathrm{Si}$ & $\mathrm{P}$ & $\mathrm{S}$ \\
\hline $3 r d$ & $\mathrm{Cl}$ & $\mathrm{Ar}$ & & $\mathrm{x}$ & & & & & $\mathrm{K}$ & $\mathrm{Ca}$ & $\mathrm{Sc}$ & $\mathrm{Ti}$ & V & $\mathrm{Cr}$ \\
\hline & $\mathrm{Mn}$ & $\mathrm{Fe}$ & $\mathrm{Co}$ & $\mathrm{Ni}$ & & & & & $\mathrm{Cu}$ & $\mathrm{Zn}$ & $\mathrm{Ga}$ & $\mathrm{Ge}$ & As & $\mathrm{Se}$ \\
\hline 4 th & $\mathrm{Br}$ & $\mathrm{Kr}$ & & & & & & & $\mathrm{Rb}$ & $\mathrm{Sr}$ & $\mathrm{Y}$ & $\mathrm{Zr}$ & $\mathrm{Nb}$ & Mo \\
\hline & $\mathrm{Tc}$ & $\mathrm{Ru}$ & $\mathrm{Rh}$ & $\mathrm{Pd}$ & & & & & $\mathrm{Ag}$ & $\mathrm{Cd}$ & In & $\mathrm{Sn}$ & $\mathrm{Sb}$ & $\mathrm{Te}$ \\
\hline 5 th & J & $\mathrm{Xe}$ & & & XI & XII & XIII & XIV & $\mathrm{Cs}$ & $\mathrm{Ba}$ & $\mathrm{La}$ & $\mathrm{Ce}$ & $\operatorname{Pr}$ & $\mathrm{Nd}$ \\
\hline & $\mathrm{Pm}$ & $\mathrm{Sa}$ & $\mathrm{Eu}$ & $\mathrm{Gd}$ & $\mathrm{Tb}$ & Dy & Ho & $\mathrm{Er}$ & $\mathrm{Tm}$ & $\mathrm{Yb}$ & $\mathrm{Lu}$ & Hf & $\mathrm{Ta}$ & W \\
\hline & $\mathrm{Re}$ & Os & Ir & $\mathrm{Pt}$ & & & & & $\mathrm{Au}$ & $\mathrm{Hg}$ & $\mathrm{Tl}$ & $\mathrm{Pb}$ & $\mathrm{Bi}$ & $\mathrm{Po}$ \\
\hline 6th & $\mathrm{At}$ & $\mathrm{Nt}$ & & & & & & & $\mathrm{Fr}$ & $\mathrm{Ra}$ & $\mathrm{Ac}$ & $\mathrm{Th}$ & $\mathrm{Pa}$ & $\mathrm{U}$ \\
\hline & $n$ & $\mathrm{Pu}$ & $\mathrm{Am}$ & $\mathrm{Cm}$ & Il & $\mathrm{Cf}$ & $\mathrm{Ei}$ & $\mathrm{Fm}$ & & & & & & \\
\hline
\end{tabular}

Fig. 1 Described as "Mendeleyev Revisited" (hereinafter abbreviated MR) 
exception of Nd [VI]. The extra two elements of the $d$-subgroups and further four elements of the $f$-subgroups are placed in new columns following group VIII, just as the extra six main group elements were added following group 0 . The first two columns are thus double-labelled: in the first three periods they are groups -1 and 0 . In subsequent periods, where they are subgroups, they are labelled groups VII and VIII. This maintains the echo of Mendeleyev's eight main groups throughout the periodic table without distortion. All the arguments for NR apply equally to MR and MR is also more compact. It requires 154 cells ( 11 rows $\times 14$ columns) against NR's 224 cells. It achieves a significant reduction in space using Scerri's novel re-arrangement (Scerri 2006) of the $s$-bloc, inspired by Döbereiner's triads.

The logical inclusion of the lanthanoids was attempted by LeRoy (1927) (Fig. 2) by reducing the $f$-groups by two in the same way as is frequently done with the $d$-groups. This is the reason that $\mathrm{Cu}-\mathrm{Ag}-\mathrm{Au}$ are placed in Group IA and $\mathrm{Zn}-\mathrm{Cd}-\mathrm{Hg}$ are in Group IIA. Similar considerations put Tm-101 in Group IB and Yb-102 in IIB.

Rather confusingly, LeRoy labels Mendeleyev's main groups 'A', Sommerfeld's A subgroups 'B' and Sommerfeld's B subgroups are labelled 'C'. But LeRoy insightfully notes the aufspaltung of $\mathrm{H}$ into $\mathrm{Li}$ and $\mathrm{F}$.

After the establishment of Lavoisier's elements, Döbereiner was the first to publish (Döbereiner 1829) any indication that they may display periodic properties by noting the correlation between chemically similar members of main groups and their atomic weights. When he framed his table, Mendeleyev was unaware of the inert gases, Group 0 , and hydrogen sat very uncomfortably above the alkali metals and was often separated off from the table into a variable, wandering position-as it still is in many tables.

When Ramsay finally completed his Group 0 ( $\mathrm{He}, \mathrm{Ne}, \mathrm{Ar}, \mathrm{Kr}, \mathrm{Xe}, \mathrm{Nt}$ ), there was no arbitrary suggestion that they completed a period. Periodicity began at the beginning, with hydrogen. Indeed, he quite explicitly (Ramsay 1915) placed his inert gases in a column following hydrogen and the halogens (Fig. 3).

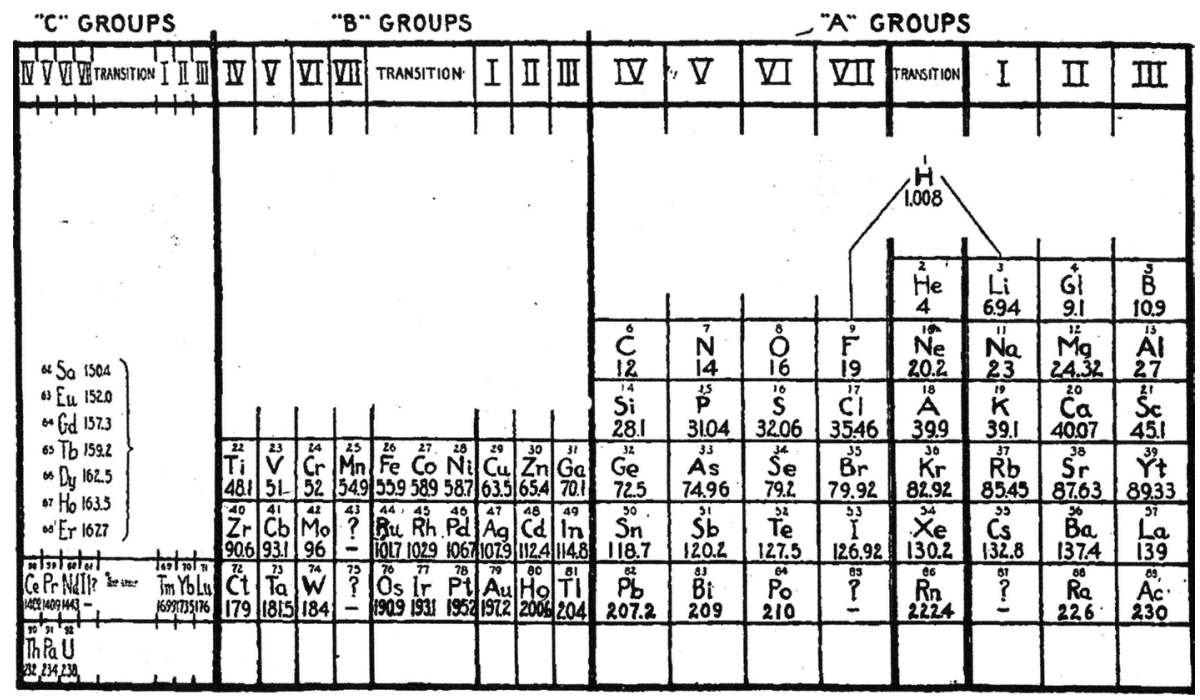

Fig. 2 Periodic Table, LeRoy 1927 


$$
\begin{aligned}
& \text { ex: Ramsay "The Gases of the Atmosphere" } \\
& 4 \text { thed. Macmillan and bo., Lordoort igis } \\
& \text { VIII THE OTHER INACTIVE GASES } 259
\end{aligned}
$$

\section{The Position of the Inadtive Elements in the}

\section{Periodic Table.}

$\begin{array}{cccc}\text { Hydrogen. } & \text { Helium. } & \text { Lithium. } & \text { Beryllium, } \\ 1 & 4 & 7 & 9 \\ \text { Fluorine. } & \text { Neon. } & \text { Sodium. } & \text { Magnesium. } \\ 19 & 20 & 23 & 24 \\ \text { Chlorine. } & \text { Argon. } & \text { Potassium. } & \text { Calcium. } \\ 35.5 & 40 & 39 & 40 \\ \text { Bromine. } & \text { Krypton. } & \text { Rubidium. } & \text { Strontium. } \\ 80 & 82 & 85 & 87 \\ \text { Iodine. } & \text { Xenon. } & \text { Caesium. } & \text { Barium. } \\ 127 & 128 & 133 & 137\end{array}$

Fig. 3 Periodic Table, Ramsay 1915

Thus the first period was seen as $\mathrm{H}, \mathrm{He}, \mathrm{Li}, \mathrm{Be}, \mathrm{B}, \mathrm{C}, \mathrm{N}, \mathrm{O}$ and then repeated as $\mathrm{F}$, $\mathrm{Ne}, \mathrm{Na}, \mathrm{Mg}, \mathrm{Al}, \mathrm{Si}, \mathrm{P}, \mathrm{S}$. Due to the 'first-member anomaly' (Scerri 2007), N and O were late to be seen as initial members of Groups V and VI and, it seems, H is still seldom seen as the first member of Group -1/VII. Yet $\mathrm{H}$ is little more different from $\mathrm{F}$ than $\mathrm{N}$ is from $\mathrm{P}$ or $\mathrm{O}$ is from $\mathrm{S}$.

The Sommerfeld splitting (aufspaltung) described in NR yields two groups from $\mathrm{H}$ (the halogens and the alkali metals) and two groups from He (the inert gases and the alkaline earth metals). Ramsay's allocation of $\mathrm{H}$ to the halogens and $\mathrm{He}$ to the inert gases follows from chemical analogy, periodicity and symmetry considerations such as the completion of triads. Mendeleyev's arrangement can be justified by the extraordinary difference between the 'daughter' groups of $\mathrm{H}$ and $\mathrm{He}$ which are chemically more different from one another than any of the main groups from each other. It also establishes two significant triads: $\mathrm{H}-\mathrm{F}-\mathrm{Cl}$ and $\mathrm{He}-\mathrm{Ne}-\mathrm{Ar}$ which are missed if $\mathrm{H}$ is classed with the alkali metals and He with the alkaline earth metals, as its IIs grouping might suggest.

It is for this chemical reason that both the halogens and the alkali metals and both the alkaline earth metals and the inert gases were four separate main groups in all early tables. By slightly rearranging $\mathrm{H}$ and $\mathrm{He}$, setting one of H's daughter groups as $-1(\mathrm{H}$ and the halogens) and one of He's daughter groups as 0 (the inert gases) beside and before group I, as in Scerri's Döbereiner-inspired table, an 11-row $\times 14$-column table is obtained, with the other pair of daughter groups as the conventional Groups I (alkali metals) and II (alkaline earth metals).

In best Popperian tradition as in NR, MR frames a hypothesis predicting a dramatic role for the hitherto obscure thulium (Gray 2009) as occupying a position between silver and 
gold in the re-arrangement of the periodic table of chemical elements. A critical test of this hypothesis would be the discovery of monovalent thulium, so far without result. A similar consideration applies to neodymium [VI] and discovery of either Tm [I] or Nd [VI] would empirically support and validate the logic of MR as a preferable 2-D arrangement of the periodic table.

\section{On the wider import of $\operatorname{Pr}[+5]$ and $\operatorname{Ir}[+9]$}

Zhang et al. (2016) report the recent discovery of $\mathrm{PrO}_{2}{ }^{+}$, confirming the existence of pentavalent praseodymium. Wang et al. (2014) report a compound ion of iridium, $\left(\mathrm{IrO}_{4}\right)^{+}$, demonstrating a valency of +9 . These discoveries lend further support to the arrangement of MR, with groups reflecting valency. Perhaps Mendeleyev, like Sanderson (1960, p. 14), would have expanded his "group VIII" to VIII, IX and X had he known about $\left(\mathrm{IrO}_{4}\right)^{+}$. A logical expectation, realized in $\mathrm{Np}^{+7}$, may be that some of the heavier lanthanoids or actinoids show a valency such as $\mathrm{Cf}^{+12}$, with positive valencies up to the Pauli maximum for each subshell. The tight binding of $f$-electrons makes this unlikely but no one expected the revision of Abegg's rule that $\left(\mathrm{IrO}_{4}\right)^{+}$requires.

\section{Chemistry revisited}

At normal temperatures and pressures, few chemists would classify hydrogen with the alkali metals. Probably fewer still would classify helium with the alkaline earth metals. That many physicists do is entirely due to considerations of electronic structure. Yet chemists had applied the Periodic Table to chemistry for half a century before the discovery of electronic structure by Bohr and Sommerfeld.

As far as hydrogen is concerned, it has a Janus-face, both physically and chemically. Its positive ion is in fact an elementary particle, the proton, no more an element than the electron is. This is not to say that protons and electrons play no part in physics or chemistry, rather they are acknowledged as basic constituents of atoms-but hardly, themselves, as atoms.

By contrast, the negative ion of hydrogen constitutes an entity in every respect analogous to the behaviour of ions of any other element. In this sense, the hydride anion is representative of hydrogen qua element whereas the hydrogen cation, a free proton, selfevidently and by definition shares the peculiar status of being both a chemical ion and an elementary particle. Since exceptional cases make bad law, we should be wary of ordering chemistry on such an outlier. It leads Petruševski and Cvetković (Petruševski and Cvetković 2018 ) to exile $\mathrm{H}$ from the periodic table altogether. Protons have a peculiar chemistry well illustrated by protonation reactions. Indeed, even electrons appear to demonstrate their own chemistry in the form of electrides, such as the solutions of alkali metals in ammonia.

Döbereiner first observed periodicity in the form of his triads and hydrogen forms a triad with the halogens not the alkali metals. Its physical existence as a diatomic gas and its chemical behaviour in forming salt-like hydrides with the alkali metals are persuasive empirical evidence for classifying hydrogen with the halogens. As an $s^{1}$ element, it is one electron short of a full $s$-subshell and so is similar, in this respect, to $d^{9}$ and $f^{13}$ elements and, of course, to the halogens, each of which is $p^{5}$, one electron short of a full $p$-subshell. Further, hydrogen's behaviour with fellow halogens in forming peculiarly active gases reflects the properties of other inter-halogen compounds. 
As described in NR, the positions of $\mathrm{H}$ and $\mathrm{He}$ in the Periodic Table arise from the Sommerfeld 'aufspaltung' of the first period, with 'daughter' subgroups of the halogens and the alkali metals from $\mathrm{H}$ and 'daughter' subgroups of the inert gases and the alkaline earth metals from He. There is little dispute, chemically, that helium belongs in the group of inert gases, Group 0. And, from the chemical considerations just outlined, hydrogen is more akin to the halogens than the alkali metals despite the undoubted subgroup relationship of both halogens and alkali metals to $\mathrm{H}$.

At the level of $s p^{3}$ hybridization, the subgroups of $\mathrm{H}$ and He remain so chemically distinct that they rightly retain the status of main groups. Rather than asking "why is Be not an inert gas?' consider the response to the question 'why is Be an alkaline earth metal?' The explanation given is usually that of $s p^{3}$ hybridization, which simply begs the question and invites us to treat the inert gases as a whole as the "II $s$ " group and the alkaline earth metals as the "II $p$ " group. The uncomfortable (for physicists) fact is that, at least in this case, electronic structure does not predict chemical properties (Sanderson 1960, p 8).

If we are to retain Mendeleyev's Hauptgruppen, we need to determine which main group should contain $\mathrm{H}$ and which He. Chemical considerations would place the former with the halogens and the latter with the inert gases. Beyond $s p^{3}$, in the $d$ - and $f$ - periods, Sommerfeld's 'aufspaltung' is explicitly recognized in the allocation of Ca to Hauptgruppe (main group) II and Zn to Nebengruppe (subgroup) IIA and in the more

Hauptgruppen (s-, sp-groups)

\begin{tabular}{|ccc|c|c|c|c|c|}
\hline -I & 0 & \multicolumn{1}{l}{$+\mathrm{I}$} & \multicolumn{1}{l}{ II } & III & \multicolumn{1}{l|}{ IV } & V & VI \\
\hline $\mathrm{H}$ & $\mathrm{He}$ & $\mathrm{Li}$ & $\mathrm{Be}$ & $\mathrm{B}$ & $\mathrm{C}$ & $\mathrm{N}$ & $\mathrm{O}$ \\
\hline $\mathrm{F}$ & $\mathrm{Ne}$ & $\mathrm{Na}$ & $\mathrm{Mg}$ & $\mathrm{Al}$ & $\mathrm{Si}$ & $\mathrm{P}$ & $\mathrm{S}$ \\
\hline $\mathrm{Cl}$ & $\mathrm{Ar}$ & $\mathrm{K}$ & $\mathrm{Ca}$ & $\mathrm{Ga}$ & $\mathrm{Ge}$ & $\mathrm{As}$ & $\mathrm{Se}$ \\
\hline $\mathrm{Br}$ & $\mathrm{Kr}$ & $\mathrm{Rb}$ & $\mathrm{Sr}$ & $\mathrm{In}$ & $\mathrm{Sn}$ & $\mathrm{Sb}$ & $\mathrm{Te}$ \\
\hline $\mathrm{J}$ & $\mathrm{Xe}$ & $\mathrm{Cs}$ & $\mathrm{Ba}$ & $\mathrm{Tl}$ & $\mathrm{Pb}$ & $\mathrm{Bi}$ & $\mathrm{Po}$ \\
\hline $\mathrm{At}$ & $\mathrm{Nt}$ & $\mathrm{Fr}$ & $\mathrm{Ra}$ & 113 & 114 & 115 & 116 \\
\hline
\end{tabular}

\section{PERIODIC TABLE}

Arnold Sommerfeld 1916 (updated construction)

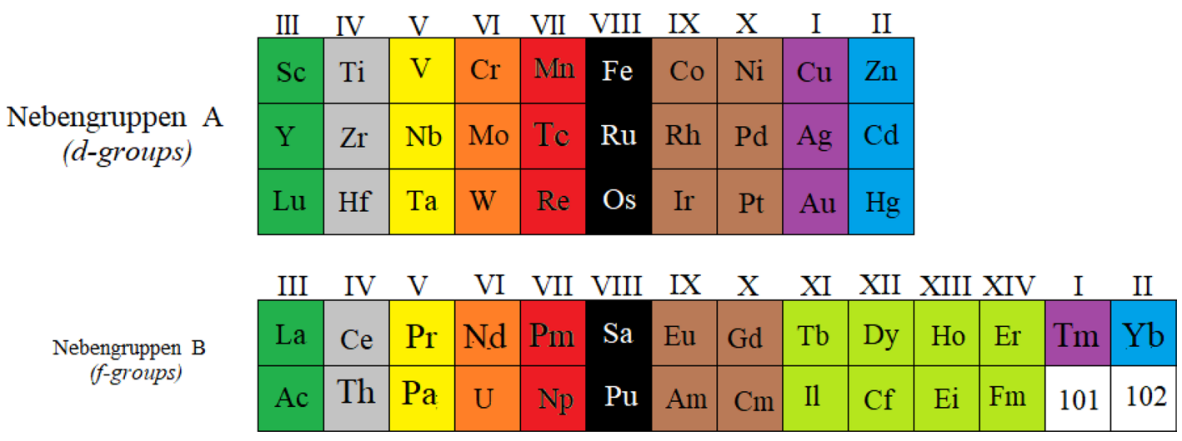

Fig. 4 Periodic Table, Sommerfeld 1916 
recent allocation (Jensen 1982) of Lu to Nebengruppe IIIA and La to Nebengruppe IIIB. Sommerfeld's Nebengruppen are thus the $d$-elements (the transition series, Nebengruppen A) and the $f$ - elements (the lanthanoids and actinoids, Nebengruppen B), with corresponding main-group valency where applicable, Fig. 4.

This may be described as a chemist's table in contrast to Janet's left-step (Janet 1929) which is a typical physicist's table. The problem of the classification of hydrogen vanishes if we accept periodicity as beginning at the beginning. Sommerfeld conflated Bohr's shells with Mendeleyev's periods and the success of this model dazzled chemists to abandoning chemical periods for physicists' electronic shells. Perhaps a compromise, with Mendeleyev's table coloured according to Sommerfeld's electronic structure, would be best (Fig. 5).

\section{IUPAC}

A decade ago, at the beginning of 2009, a IUPAC editorial (Meyers 2009) offered "something old, something new, something borrowed and something blue" in an issue devoted to IUPAC's position, inter alia, on the periodic table. In response to that debate, MR preserves the old subgroups (Newlands' columns) that were a feature of all short forms, although MR would then have been described as a 'medium form' (14 groups) in contrast to Mendeleyev's 'short form' (8 groups) or Werner's 'long form' (32 groups) (Werner 1905). MR naturally continues the subgrouping of the lanthanoids and actinoids whose initial four groups were also included in 'short form' tables. The logic of the arrangement of the $s$-elements is the new feature of MR. It recognizes the chemical subgroups of hydrogen, viz. the alkali metals and the halogens, and of helium, viz. the alkaline earth metals and the inert gases. It is interesting to note that subgroups arising from aufspaltung differ chemically from each other inversely as the azimuth, i.e. $\mathrm{Li}: \mathrm{F}>>\mathrm{Ca}: \mathrm{Zn}>\mathrm{La}: \mathrm{Lu}$. The whole idea of MR is, of course, borrowed from Sommerfeld. The group numbers are borrowed from valency but also from electronic structure in that the number of $s^{-}, p^{-}, d-$ or $f$ - subgroups

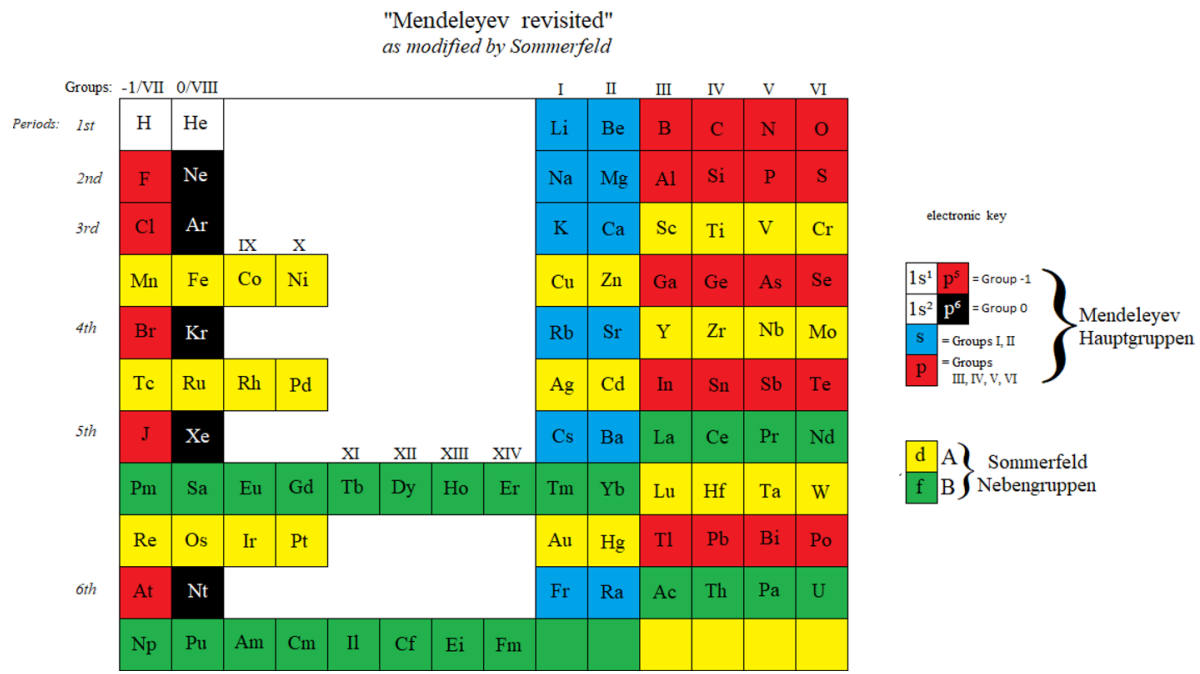

Fig. 5 Mendeleyev-Sommerfeld PT, Marks 2021 
(Mendeleyev's Hauptgruppen [s- \& $p$-] plus Sommerfeld's Nebengruppen $[d-\& f-]$ ) corresponds to the Pauli maximum for each. Finally, the colour mnemonic reflects that most elementary introduction to chemistry: alkalis turn Litmus blue. From this start, the $p$-bloc is red, the transition elements yellow and the "rare earth" elements green, as argued in NR. The numbering of groups I-XIV is unambiguous, it is less than IUPAC's arbitrary 18 groups, it preserves subgroups and satisfactorily accommodates hydrogen and the lanthanoids and actinoids. As required by Leigh (2009), this table is clear, simple and brief.

Open Access This article is licensed under a Creative Commons Attribution 4.0 International License, which permits use, sharing, adaptation, distribution and reproduction in any medium or format, as long as you give appropriate credit to the original author(s) and the source, provide a link to the Creative Commons licence, and indicate if changes were made. The images or other third party material in this article are included in the article's Creative Commons licence, unless indicated otherwise in a credit line to the material. If material is not included in the article's Creative Commons licence and your intended use is not permitted by statutory regulation or exceeds the permitted use, you will need to obtain permission directly from the copyright holder. To view a copy of this licence, visit http://creativecommons.org/licenses/by/4.0/.

\section{References}

Avogadro, A.: Essai d'une manière de déterminer les masses relatives des molécules élémentaires des corps, et les proportions selon lesquelles elles entrent dans ces combinaisons. J. Phys. 73, 58-76 (1811) (English in: "Foundations of Molecular Theory" Alembic Club Reprint 4, Edinburgh 1898).

Bohr, N.: On the constitution of atoms and molecules. Philos. Trans. 26, 1-24, 476-502 and 857-875 (1913).

Boyle, R.: "The Sceptical Chymist" Crook, London 1661. Dover, New York (2003)

Christie. J.: 'Why is Beryllium not Considered a Noble Gas? (2001). www.madsci.org/posts/archives/200104/988047875.Ch.r.html. Accessed 3 Apr 2021

Döbereiner, J. W.: "Versuch zu einer Gruppierung der elementaren Stoffe nach ihrer Analogie" Poggendorf's Annalen der Physik und Chemie, Leipzig 15, 301-307 (1829) (English in Leicester HM, Klickstein HS “A Source Book in Chemistry 1400-1900” Havard UP, Cambridge 1952, pp. 268-272).

Faraday, M.: Experimental researches in electricity. Philos. Trans. R. Soc. 123, 675-710 (1833) and 124, 77-122 (1834) (Great Books of the Western World 1988, 45: 253-866, "Electrochemistry" at $\$ 450$ 563 \& $\$ \$ 661-874$. William Benton, Britannica, Chicago 1988)

Gray, T.: The Elements, p. 159. Black Dog \& Leventhal, New York (2009)

Greenwood, N.N., Earnshaw, A.: Chemistry of the Elements, pp. 25-26. Pergamon, Oxford (1993)

Janet, C.: The helicoidal classification of the elements. Chem. News 138, 388-393 (1929)

Jensen, W.B.: The positions of lanthanum (actinium) and lutetium (lawrencium) in the periodic table. J. Chem. Ed. 59, 634-636 (1982)

Lavoisier, A.: Traité élémentaire de chimie. Cuchet, Paris (1789) (English in "Great Books of the Western World" 1988, 45: 1-159. William Benton, Britannica, Chicago, 1988).

LeRoy, R.H.: Teaching the periodic classification of elements. School Sci. Math. 27, 793-799 (1927)

Leigh, G.J.: Periodic Tables and IUPAC. Chem. Int. 31, 4-6 (2009)

Marks, E.G., Marks, J.A.: Newlands revisited. Found. Chem. 12, 85-93 (2010)

Mendeleyev, D.I.: Соотношение свойств с атомным весом элементов. Жнл Русс Хим Общ 1, 60-77

(1869) (English in Jensen WB, "Mendeleev and the Periodic Law" Dover, New York 2005).

Meyers, F.: From the editor. Chem. Int. 31, 1-2 (2009)

Petruševski, V.M., Cvetković, J.: On the "true position" of hydrogen in the periodic table. Found. Chem. 20, 251-260 (2018)

Ramsay, W.: The Gases of the Atmosphere, 4th edn. Methuen, London (1915)

Sanderson, R.T.: Chemical Periodicity. Reinhold, New York (1960)

Scerri, E. R.: What if the periodic table starts and ends with triads? PhilSci Arch. 3095 (2006).

Scerri, E.R.: The Periodic Table, pp. 275-276. OUP, Oxford (2007)

Sommerfeld, A.: Zur Quantentheorie der Spektrallinien. Ann. Phys. 51, 1-94 and 125-167 (1916) (English in "Atomic Structure and Spectral Lines” Methuen, London 1923). 
Wang, G.J., et al.: Identification of an iridium-containing compound with a formal oxidation state of IX. Nature 514, 475-477 (2014)

Werner, A.: Beitrag zum Ausbau des periodischen Systems. Ber Deut Chem. Ges. 38, 914-921 (1905) (English in Chem Soc Abstr 1905, 88: 308-9).

Zhang, Q.N., et al.: Pentavalent lanthanide compounds. Angew. Chem. 55, 6896-6900 (2016)

Publisher's Note Springer Nature remains neutral with regard to jurisdictional claims in published maps and institutional affiliations. 